\title{
Dry Anaerobic Co-Digestion of Citrus Wastes with Keratin and Lignocellulosic Wastes: Batch And Continuous Processes
}

\author{
Regina J. Patinvoh ${ }^{1,2} \mathbb{D} \cdot$ Magnus Lundin $^{1} \cdot$ Mohammad J. Taherzadeh $^{1} \cdot$ llona Sárvári Horváth ${ }^{1}$
}

Received: 13 April 2018 / Accepted: 5 September 2018 / Published online: 14 September 2018

(c) The Author(s) 2018

\begin{abstract}
Dry anaerobic co-digestion of citrus wastes (CW) with chicken feather (CF), wheat straw (WS) and manure bedded with straw (MS) was investigated in batch and continuous processes. Experiments were designed with different mixing ratios considering the inhibitory effect of $\mathrm{CW}, \mathrm{C} / \mathrm{N}$ ratio, and total solid content of individual feedstocks. Best mixing ratio (CF:CW:WS:MS) of 1:1:6:0, enhanced methane yield by $14 \%$ compared to the expected yield calculated according to the methane yields obtained from the individual fractions. The process performance of this mixture was then investigated in continuous plug flow reactors at different organic loading rates (OLR) with feedstock total solid contents of $21 \% \mathrm{TS}\left(\mathrm{R}_{\mathrm{TS} 21}\right)$ and $32 \% \mathrm{TS}\left(\mathrm{R}_{\mathrm{TS} 32}\right)$. At OLR of $2 \mathrm{gVS} / \mathrm{L} / \mathrm{d}$, a methane yield of $362 \mathrm{NmlCH}_{4} / \mathrm{gVS}_{\text {added }}$ was obtained from $\mathrm{R}_{\mathrm{TS} 21}$, which is $13.5 \%$ higher than the yield obtained from $\mathrm{R}_{\mathrm{TS} 32}\left(319 \mathrm{NmlCH}_{4} / \mathrm{gVS}_{\text {added }}\right.$ ). However, it was not possible to achieve a stable process when the OLR was further increased to $3.8 \mathrm{gVS} / \mathrm{L} / \mathrm{d}$; there were increased total VFAs concentrations and a decline in the biogas production.
\end{abstract}

Keywords Solid wastes $\cdot$ Dry co-digestion $\cdot$ Batch process $\cdot$ Continuous process $\cdot$ Process performance

\section{Statement of Novelty}

Appropriate mixing ratio for dry codigestion of inhibitory and recalcitrant wastes was acquired for improved methane yield. This is to circumvent some problems associated with pretreatment of these wastes and also make the dry digestion process more economical.

Regina J. Patinvoh

regina.patinvoh@hb.se

Magnus Lundin

magnus.lundin@hb.se

Mohammad J. Taherzadeh

mohammad.taherzadeh@hb.se

Ilona Sárvári Horváth

ilona.horvath@hb.se

1 Swedish Centre for Resource Recovery, University of Borås, SE 501-90, Borås, Sweden

2 Department of Chemical and Polymer Engineering, Faculty of Engineering, Lagos State University, Lagos, Nigeria

\section{Introduction}

Global emissions from solid wastes are estimated to be between 20 and 40 million tons of $\mathrm{CH}_{4}$ per year [1]. Biogas production from these waste streams through anaerobic digestion processes reduces greenhouse gas emissions and solve the problem of global energy challenge and environmental threat [2]. Solid waste streams like chicken feathers (CFs), manure bedded with straw (MS), wheat straw (WS) and other agricultural and forest residues are readily available; they account for the largest potential feedstock as sources of biomass energy. CF is a good potential source of nitrogen with over $90 \%$ of crude protein content [3, 4], and WS is mainly carbohydrate; a potential source of carbon. Additionally, fruit wastes contain a large amount of organic matter that are easily degraded with about $78.3 \%$ carbohydrates, $8.5 \%$ protein, and $6 \%$ fat [5], which makes them potential source of biomass for energy production. Large volume of fruit wastes are also generated globally; over 40 million tons of industrial citrus wastes (CW) are globally generated [6]. Converting these waste streams into energy through anaerobic digestion is a feasible option with low capital investment thereby ascribing value to these wastes.

Notably, because of the recalcitrant structure of most agricultural solid wastes such as CFs and WS, they degrade 
slowly, thus, resulting in low biogas yield. Other problems associated with the digestion of these waste streams are the high nitrogen or carbon content, leading to a nutrient imbalance when they are digested as the sole substrate. Several research studies have been conducted to improve the methane yield from keratin-rich and lignocellulosic solid wastes by chemical pretreatment [7-11], steam explosion pretreatment [12], and biological pretreatment [3, 13, 14]. Additionally, the presence of peel oil, with D-limonene as the main ingredient in $\mathrm{CW}$, inhibits microbial growth [15], leading to a low biogas yield. This inhibition challenge in $\mathrm{CW}$ for biogas production has been addressed by leaching [16], steam explosion pretreatment [17], and membrane technology [18]. Although these methods have been reported to be effective in solving problems with low biogas yield, there are still problems of high energy consumption, expensive technology, harmful environmental by-products, and release of inhibitors during some of the pretreatment methods [19].

Considering the fact that easily degraded feedstocks are not readily available and the challenges associated with some pre-treatments methods, co-digestion is an alternative strategy for improving the biogas yield from these types of solid wastes. This concept favors synergisms, dilutes harmful compounds, optimizes the biogas production, and increases the digestate quality [20]. Although nitrogen is an essential nutrient for the microorganisms, its excess leads to the formation of ammonia during degradation, which inhibits microbial growth at higher concentrations [21, 22]. Additionally, when the amounts of easily degradable carbon are too high, the process tends to be susceptible to acid accumulation [23]. Presence of inhibitor in some feedstocks also affects the microbial growth. Hence, there is need for codigestion to enhance buffering capacity and reduce inhibitory effect on biogas yield. A considerably wider $\mathrm{C} / \mathrm{N}$ ratio, between 10:1 and 30:1, has been reported in the literature for a stable digestion process [22, 24]. Nevertheless, the composition of feedstocks, the availability of carbon and nitrogen to the microbial community [25], and different operation parameters during the digestion process are also significant for an effective anaerobic digestion.

There has been great concern over large volume of water used during anaerobic digestion of solids wastes and in the digestate residue. To address this challenge, recent studies have focused on dry anaerobic digestion of these waste streams [26-30]. However, dry digestion of these wastes requires further improvement for industrial applications; there is a challenge of longer retention time and low mass transfer at higher solid content [31, 32]. Co-digestion of multiple feedstocks is a feasible option for addressing these challenges [32]. Present study investigates co-digestion of $\mathrm{CW}$ with $\mathrm{CFs}$, WS, and MS in a dry anaerobic digestion process. Experiments were designed with different mixing ratios and evaluated in batch process. In addition, the process performance of the best mixture in batch was investigated in continuous plug flow reactors at different organic loading rates (OLR) with feedstock total solid contents of $21 \%$ TS and $32 \%$ TS.

\section{Materials and Methods}

\section{Substrates and Inoculum}

The different substrates used during this study were CFs, $\mathrm{CW}$, WS, and cattle MS. The CF waste was collected from a slaughterhouse (Håkantorp Slakteri AB, Håkantorp, Sweden) and prepared according to Patinvoh et al. [3] prior to use; the particle size of the CF was between 1 and $10 \mathrm{~mm}$. $\mathrm{CW}$ were obtained from Brämhults Juice $\mathrm{AB}$ (Borås, Sweden) and chopped manually. WS and cattle MS were obtained from a farm outside Borås (Rådde Gård, Sweden). The manure was shredded manually to reduce the particle size of straw in the manure to an average of $2 \mathrm{~mm}$, and the WS was milled to a particle size between 0.5 and $2 \mathrm{~mm}$. The $\mathrm{CF}$ wastes and WS were stored at room temperature, while the $\mathrm{CW}$ and MS were stored in plastic containers at $-20^{\circ} \mathrm{C}$ until further use. During the experiment, weighted frozen substrates were thawed at room temperature and thoroughly mixed to gain a homogenized feed before use.

Prior to analysis, the feedstocks being solids were prepared according to Zupančič and Roš [33] by blending $1 \mathrm{~g}$ of the sample with water (dilution factor of 50) to allow homogenization. Thereafter, the theoretical methane potential $\left(\mathrm{BMP}_{\text {thCOD }}\right)$ of the feedstocks used were calculated related to their chemical oxygen demand (COD) content as described previously [27], after determining the COD content for the individual feedstocks using Eq. (1) [34] assuming that the equation is valid for any substance or product [35].

$$
\mathrm{BMP}_{\text {thCOD }}=\frac{\mathrm{n}_{\mathrm{CH}_{4}} \mathrm{RT}}{\mathrm{pVS}_{\text {added }}}
$$

where $\mathrm{BMP}_{\text {thCOD }}$ is theoretical yield under laboratory condition, $\mathrm{R}$ is gas constant $\left(0.082 \mathrm{~atm} \mathrm{~L} / \mathrm{mol}{ }^{\circ} \mathrm{K}\right)$, $\mathrm{T}$ is working temperature $\left(310^{\circ} \mathrm{K}\right), \mathrm{P}$ is pressure $(1 \mathrm{~atm}), \mathrm{VS}_{\text {added }}$ is volatile solids (VS) of the substrate added $(\mathrm{g})$, and $\mathrm{n}_{\mathrm{CH} 4}$ is methane produced (mol) determined according to Eq. (2):

$\mathrm{n}_{\mathrm{CH}_{4}}=\frac{\mathrm{COD}}{64\left(\frac{\mathrm{g}}{\mathrm{mol}}\right)}$

However, the COD content of CFs was not detectable because the mixture was heterogeneous; therefore, the theoretical methane yield of $496 \mathrm{Nml}$ methane produced per $\mathrm{g}$ 
VS for proteins [36] was used for the calculations, which is applicable if all the insoluble protein (keratin) are converted to soluble protein.

Anaerobic sludge used as inoculum was obtained from a digester treating wastewater sludge and operating at mesophilic conditions (Vatten and Miljö i Väst AB, Varberg, Sweden). This inoculum was incubated at $37{ }^{\circ} \mathrm{C}$ prior to use; the inoculum with $3.8 \%$ TS and $2.7 \%$ VS was then centrifuged at $10,000 \times g$ for $10 \mathrm{~min}$ to increase its TS content to $9.43 \%$ and VS content to $6.44 \%$. Table 1 shows the characteristics of the substrates and the anaerobic sludge (inoculum) used during the experiments.

\section{Statistical Design}

The experiment was designed with statistical software MINITAB ${ }^{\circledR}$ (version 17.1.0), using 3-factor simplex lattice design, consisting of pure substrates and mixtures of two, three, and four substrates at wet weight ratios. The CF fraction was kept constant to maintain the $\mathrm{C} / \mathrm{N}$ ratio of the mixtures between 12 and 21 . The experiments were replicated according to the same setups and methane yield was used as response variable. The linear mixing model was used to obtain the expected methane yield from all the mixtures without synergetic or antagonistic interactions; the methane yield is expected to correspond to the amount of VS fractions from individual substrates. The quadratic model was used to obtain the predicted methane yield from all the mixtures; this measures the synergetic or antagonistic interactions between VS fractions of individual substrates. Table 2 shows the mixture compositions following the simplex lattice design.

\section{Batch Anaerobic Dry Digestion of the Individual Substrates and Mixtures}

Anaerobic batch digestion tests on individual substrates and the co-digestion mixtures were performed according to the method described by Angelidaki, Alves [37]. The assays were carried out under mesophilic conditions $\left(37 \pm 1{ }^{\circ} \mathrm{C}\right)$ using $118 \mathrm{ml}$ serum glass bottles as reactors; each reactor contained $39 \mathrm{ml}$ of inoculum and $1.25 \mathrm{gVS}$ of individual substrates and mixtures, keeping a VS ratio $\left(\mathrm{VS}_{\text {substrate }}\right.$ to $\left.\mathrm{VS}_{\text {inoculum }}\right)$ at 1:2 in all setups. The total solid content of the individual substrates and mixtures were adjusted to $20 \%$ TS, the mixture compositions used in the various set ups are shown in Table 2. Inoculum and water was used as blanks for the determination of methane production from the inoculum itself. The $\mathrm{pH}$ in all the reactors was adjusted to $7.0 \pm 1$ using $2 \mathrm{M} \mathrm{NaOH}$ and $\mathrm{HCl}$ solution, then the reactors were sealed with rubber septa and aluminum caps, and the headspace was flushed with a gas mixture of $80 \% \mathrm{~N}_{2}$ and $20 \% \mathrm{CO}_{2}$ for $2 \mathrm{~min}$ to create an anaerobic environment in each setup. The reactors were placed in an incubator at $37 \pm 1^{\circ} \mathrm{C}$ and were shaken manually once a day during the incubation period of 82 days. All experimental setups were performed in duplicates, and gas samples were taken twice a week during the process and once a week toward the end of the digestion period.

\section{Co-Digestion of the Best Mixture in the Plug Flow Reactors}

The best mixing ratio, i.e., the mixture with the highest methane yield, as determined from the batch process was applied in the continuous co-digestion process using plug flow reactors. The reactor has an impeller installed on a hexagonal shaft that runs through the inlet to the outlet. This impeller allowed mixing of the feedstock at the bottom part of the inlet, and transported the materials very slowly towards the outlet taking several rotations depending on the viscosity of feedstock and working volume of reactor. The plug flow reactors worked as described previously [27], with a working volume of $5 \mathrm{~L}$.

The first part of the experiment was to carry out batch digestion in plug flow reactors with the same condition used in the serum bottles $(118 \mathrm{ml})$; this was done to adapt the inoculum to the feedstock. The plug flow reactors

Table 1 Characteristics of the substrates and inoculum (mean values and standard deviations based on triplicate measurements)

\begin{tabular}{|c|c|c|c|c|c|c|c|c|c|}
\hline Substrates & $\mathrm{pH}$ & Bulk density $(\mathrm{g} / \mathrm{L})$ & TS (\%) & $\operatorname{VS}(\%)^{*}$ & $\operatorname{Ash}(\%)^{*}$ & Total carbon $(\%)^{*}$ & $\operatorname{TKN}(\%)^{*}$ & $\mathrm{C} / \mathrm{N}$ & $\begin{array}{l}\mathrm{COD} \\
\mathrm{gCOD} / \\
\mathrm{gVS}_{\text {substrate }}\end{array}$ \\
\hline Chicken feather & ND & ND & $93.47 \pm 0.06$ & $99.26 \pm 0.01$ & $0.74 \pm 0.01$ & $55.14 \pm 0.01$ & $15.50 \pm 0.30$ & 3.6 & ND \\
\hline Citrus wastes & 3.24 & $753.60 \pm 24.32$ & $23.42 \pm 2.23$ & $96.07 \pm 0.74$ & $3.93 \pm 0.74$ & $53.37 \pm 0.41$ & $0.99 \pm 0.08$ & 55.5 & 1.03 \\
\hline Wheat ${ }^{\mathrm{a}}$ straw & ND & $190.47 \pm 6.93$ & $89.07 \pm 0.08$ & $94.96 \pm 0.14$ & $5.04 \pm 0.14$ & $52.76 \pm 0.08$ & $0.83 \pm 0.08$ & 69 & 0.89 \\
\hline Manure with straw & 8.01 & $542.00 \pm 26.87$ & $25.84 \pm 0.92$ & $77.21 \pm 2.74$ & $22.79 \pm 2.74$ & $42.89 \pm 1.52$ & $2.26 \pm 0.04$ & 19 & 0.89 \\
\hline Anaerobic sludge & 8.19 & $1006.7 \pm 5.52$ & $9.43 \pm 0.09$ & $68.29 \pm 0.01$ & $29.43 \pm 0.35$ & $39.20 \pm 0.19$ & $4.73 \pm 0.18$ & 8.3 & ND \\
\hline
\end{tabular}

$T K N$ total kjeldahl nitrogen, $C / N$ carbon to nitrogen ratio, $C O D$ chemical oxygen demand, $N D$ not determined

${ }^{a}$ Extractives $8.27 \%^{*}$, Total lignin $16.52 \%^{*}$, Cellulose $42.74 \%^{*}$, Hemicellulose $27.99 \%^{*}$ — Dry basis 
Table 2 Mixture compositions used in the batch anaerobic co-digestion process

\begin{tabular}{|c|c|c|c|c|c|c|c|c|c|c|}
\hline \multirow[t]{3}{*}{ Mixing ratios ${ }^{\mathrm{a}}$} & \multirow[t]{3}{*}{ Mixtures } & \multirow[t]{3}{*}{$\mathrm{C} / \mathrm{N}$} & \multicolumn{8}{|c|}{ Mixing compositions } \\
\hline & & & \multicolumn{2}{|c|}{ Chicken feather $(\mathrm{CF})$} & \multicolumn{2}{|c|}{ Citrus wastes $(\mathrm{CW})$} & \multicolumn{2}{|c|}{ Wheat straw (WS) } & \multicolumn{2}{|c|}{$\begin{array}{l}\text { Manure with straw } \\
\text { (MS) }\end{array}$} \\
\hline & & & $\%^{\mathrm{b}} \mathrm{g}_{\text {added }}$ & $\% \mathrm{VS}_{\text {added }}$ & $\%^{\mathrm{b}} \mathrm{g}_{\text {added }}$ & $\% \mathrm{VS}_{\text {added }}$ & $\%^{\mathrm{b}} \mathrm{g}_{\text {added }}$ & $\% \mathrm{VS}_{\text {added }}$ & $\%^{\mathrm{b}} \mathrm{g}_{\text {added }}$ & $\% \mathrm{VS}_{\text {added }}$ \\
\hline 1:1:1:5 & M1 & 14 & 3.4 & 12.5 & 14.0 & 12.5 & 3.7 & 12.5 & 78.9 & 62.5 \\
\hline $1: 1: 5: 1$ & M2 & 19 & 6.6 & 12.5 & 27.0 & 12.5 & 35.9 & 62.5 & 30.5 & 12.5 \\
\hline 1:1:0:6 & M3 & 13 & 3.0 & 12.5 & 12.5 & 12.5 & 0 & 0 & 84.5 & 75 \\
\hline 1:1:6:0 & M4 & 21 & 8.5 & 12.5 & 35.2 & 12.5 & 56.2 & 75 & 0 & 0 \\
\hline $1: 0.5: 2.2: 4.3$ & M5 & 15 & 3.9 & 12.5 & 8.1 & 6.25 & 9.3 & 27.1 & 78.8 & 54.2 \\
\hline $1: 0.5: 4.3: 2.2$ & M6 & 17 & 5.6 & 12.5 & 11.5 & 6.25 & 26.6 & 54.2 & 56.3 & 27.1 \\
\hline $1: 0.5: 1.1: 5.4$ & M7 & 14 & 3.4 & 12.5 & 7.0 & 6.25 & 4.0 & 13.5 & 85.6 & 67.7 \\
\hline $1: 0.5: 5.4: 1.1$ & M8 & 19 & 7.1 & 12.5 & 14.7 & 6.25 & 42.3 & 67.7 & 35.9 & 13.5 \\
\hline $1: 0.5: 0: 6.5$ & M9 & 13 & 3.0 & 12.5 & 6.2 & 6.25 & 0 & 0 & 90.8 & 81.3 \\
\hline 1:0.5:6.5:0 & M10 & 21 & 9.8 & 12.5 & 20.2 & 6.25 & 70 & 81.3 & 0 & 0 \\
\hline $1: 0.25: 2.25: 4.5$ & M11 & 14 & 3.9 & 12.5 & 4.1 & 3.125 & 9.7 & 28.1 & 82.3 & 56.3 \\
\hline $1: 0.25: 4.5: 2.25$ & M12 & 17 & 5.7 & 12.5 & 5.9 & 3.125 & 28.3 & 56.3 & 60 & 28.1 \\
\hline $1: 0.25: 0: 6.75$ & M13 & 12 & 3.0 & 12.5 & 3.1 & 3.125 & 0 & 0 & 93.9 & 84.4 \\
\hline 1:0.25:6.75:0 & M14 & 21 & 10.6 & 12.5 & 10.9 & 3.125 & 78.5 & 84.4 & 0 & 0 \\
\hline 1:0:1.2:5.8 & M15 & 13 & 3.4 & 12.5 & 0 & 0 & 4.3 & 14.6 & 92.3 & 72.9 \\
\hline 1:0:5.8:1.2 & M16 & 19 & 7.8 & 12.5 & 0 & 0 & 49.9 & 72.9 & 42.3 & 14.6 \\
\hline 1:0:0:7 & M17 & 12 & 3.0 & 12.5 & 0 & 0 & 0 & 0 & 97 & 87.5 \\
\hline 1:0:7:0 & M18 & 21 & 11.5 & 12.5 & 0 & 0 & 88.5 & 87.5 & 0 & 0 \\
\hline
\end{tabular}

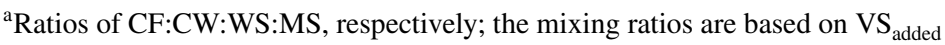

${ }^{\mathrm{b}}$ Wet basis

were loaded with the feedstock at $20 \%$ TS and inoculated with anaerobic sludge; VS ratio ( $\mathrm{VS}_{\text {substrate }}$ to $\mathrm{VS}_{\text {inoculum }}$ ) was kept at 1:2, thereby, having a TS of $11 \%$ in the reactors. The process was operated in batch mode for 28 days while the TS in the bioreactors was reduced to around $4 \%$ TS. Since the co-digestion process was studied under dry digestion, the TS in the reactors were increased to $15 \%$ by adding fresh feedstock to the acclimatized inoculum, achieving a VS ratio ( $\mathrm{VS}_{\text {substrate }}$ to $\mathrm{VS}_{\text {inoculum }}$ ) of 2.5:1. Thereafter, the continuous feeding operation began after a startup phase of 32 days. Reactors were fed every day; reactor $1\left(\mathrm{R}_{\mathrm{TS} 21}\right)$ was fed with a feedstock of $21 \% \mathrm{TS}$ and reactor $2\left(\mathrm{R}_{\mathrm{TS} 32}\right)$ was fed with a feedstock of $32 \% \mathrm{TS}$. The process was investigated at OLR of $2.0 \mathrm{gVS} / \mathrm{L} / \mathrm{d}$ (OLR 1) and $3.8 \mathrm{gVS} / \mathrm{L} / \mathrm{d}$ (OLR 2) with corresponding retention times of 50 and 30 days, respectively. During the feeding, equivalent amounts of the digestate residue were withdrawn from the reactors every day; the digestate was mixed with fresh feedstock in a ratio of $1: 2$ (feedstock: digestate; wet basis) prior to the feeding. The impeller has described above was rotated manually (once daily) to allow flow of reactor content to the inlet and back to the outlet in order to minimize stratification in the reactor. Process parameters such as the volume of biogas produced, methane content of the produced biogas, $\mathrm{pH}$, TS,
VS, VFA/Alkalinity ratio, total VFA, and total ammonia concentration were monitored regularly during the digestion process.

\section{Analytical Methods}

Total solids (TS), VS, pH, and ash content were determined according to the biomass analytical procedures [38]. Total nitrogen contents (TKN) were measured using the Kjeldahl method. The total carbon was obtained by correcting the total dry weight carbon value for the ash content [39], and the bulk density was determined according to Zhang et al. [40]. COD concentrations were analyzed using a COD test kit (Nanocolor, MACHEREY-NAGEL $\mathrm{GmbH} \&$ Co. KG. Germany), and the concentrations were then measured using a Nanocolor 500D Photometer (MACHEREY-NAGEL GmbH \& Co. KG. Germany). Extractives in the WS samples were determined according to the NREL protocol [41], using the Soxhlet method with successive water and ethanol extraction for $24 \mathrm{~h}$. The total carbohydrate and total lignin content of the extractive free straw samples were then determined according to the NREL protocols [42]. The monomeric sugars obtained during the hydrolysis were determined by HPLC; a UVabsorbance detector (Walters 2487) operating at $210 \mathrm{~nm}$ 
wavelength was used in series with a refractive index (RI) detector (Walters 2414) operating at $60{ }^{\circ} \mathrm{C}$. Mannose, glucose, galactose, xylose, and arabinose were analyzed using an Aminex HPX-87P column (Bio-Rad) at $85^{\circ} \mathrm{C}$ and $0.6 \mathrm{~mL} / \mathrm{min}$ ultrapure water as an eluent. Acid soluble lignin (ASL) was determined using an UV spectrophotometer (Biochrom Ltd., Cambridge, England) at $320 \mathrm{~nm}$. Acid insoluble lignin (AIL) was gravimetrically determined as residual solid after hydrolysis was corrected with the ash content. The ash content was determined as the remaining residue after keeping the samples in the muffle furnace at $575^{\circ} \mathrm{C}$ for $24 \mathrm{~h}$.

Samples of the digestates obtained from the reactors in the continuous experiment were centrifuged $(5000 \times g$ for $10 \mathrm{~min}$ ); thereafter, the supernatant diluted 50 times was analyzed for total ammonia concentration using the Ammonia rapid test kits (Megazyme, Megazyme International Ireland, Ireland), and the concentrations were measured at $340 \mathrm{~nm}$ wavelength using a spectrophotometer (Biochrom Ltd., Cambridge, England). Alkalinity was measured as the total inorganic carbonate and was determined by the Nordmann titration method, according to Lossie and Pütz [43]. Digestate samples were centrifuged at $5000 \times g$ for $10 \mathrm{~min}$, and then $5 \mathrm{ml}$ of the supernatant was titrated with $0.1 \mathrm{~N}$ sulfuric acid to $\mathrm{pH} 5$; the titration was then continued until $\mathrm{pH} 4.4$ was reached in order to determine the VFA concentration measured as the acetic acid equivalent. Total VFAs in the digestate filtrates were measured using a high-performance liquid chromatograph (HPLC, water 2695, Waters Corporation, Milford, MA, U.S.A.) equipped with an RI detector (Waters 2414, Waters Corporation, Milford, MA, U.S.A.) and a biohydrogen-ion exchange column (Aminex HPX-87H, Bio-Rad, Hercules, CA, U.S.A.) operating at $60^{\circ} \mathrm{C}$. A UVabsorbance detector (Walters 2487) operating at $210 \mathrm{~nm}$ wavelength was used in series with a RI detector (Walters 2414) operating at $60{ }^{\circ} \mathrm{C}$.

Gas samples, taken from the headspace of each batch reactor using a $250 \mu \mathrm{l}$ pressure-lock gas syringe (VICI, precious sampling Inc., U.S.A.), were analyzed with a gas chromatograph (Perkin-Elmer, U.S.A.) equipped with a packed column $\left(6^{\prime} \times 1.8^{\prime \prime}\right.$ OD, $80 / 100$, Mesh, Perkin Elmer, U.S.A. $)$ and a thermal conductivity detector (Perkin-Elmer, U.S.A.) with an inject temperature of $150{ }^{\circ} \mathrm{C}$. The carrier gas was nitrogen operated with a flow rate of $20 \mathrm{ml} / \mathrm{min}$ at $60{ }^{\circ} \mathrm{C}$. Gas measurement and analysis were carried out as described previously [44]. The biogas volume from the continuous plug flow reactors was measured with a drum-type gas meter (TG 05 Model 5, Ritter, Germany) and was corrected for reporting at standard temperature and pressure $\left(0{ }^{\circ} \mathrm{C}\right.$, and $1 \mathrm{~atm})$ using the ideal gas law. The methane content of the biogas produced was determined with gas chromatograph as described above.

\section{Results and Discussion}

\section{Substrates and Inoculum Composition}

Characteristics of the feedstocks examined in this study are presented in Table 1; all the substrates had a solid content of between $23 \%$ and $93 \%$, which makes them suitable for dry anaerobic digestion. $\mathrm{CF}$ had the lowest $\mathrm{C} / \mathrm{N}$ ratio (3.6) due its high nitrogen content, while WS had the highest $\mathrm{C} / \mathrm{N}$ ratio (69) as a result of its high carbon content. $\mathrm{CW}$ also contained high carbon, but very low nitrogen, while MS had higher nitrogen content compared to that in citrus waste (CW) and WS. Additionally, CW were the only acidic waste of all the substrates investigated, with its $\mathrm{pH}$ of 3.24; moreover, it had previously been reported to contain $3.78 \%$ of limonene [45] inhibiting methanogens [15]. All the different mixing ratios examined in this study had a $\mathrm{C} / \mathrm{N}$ ratio between 12 and 21 which is within the optimal $\mathrm{C} / \mathrm{N}$ range required for a stable anaerobic digestion process $[22,24]$.

\section{Methane Yield from Individual Substrates}

The theoretical maximum methane potential of the individual feedstocks calculated based on the COD content, together with the experimental results of methane yields obtained during the batch anaerobic digestion are presented in Fig. 1. Mono-digestion of $\mathrm{CW}$ resulted in a methane yield of $137 \mathrm{NmlCH}_{4} / \mathrm{gVS}$, which is $33 \%$ of the theoretical maximum yield. This is in accordance with the methane yields of $102 \mathrm{NmlCH}_{4} / \mathrm{gVS}$ [17] and 131 $\mathrm{NmlCH}_{4} / \mathrm{gVS}$ (homogenized) [16] for similar substrates obtained earlier under thermophilic wet digestion conditions. CW degrade easily, but the methane yield is low due to the presence of D-limonene which is inhibitory to the microbial community, as reported previously by several researchers [15, 18]. Furthermore, the methane yield from CFs was $132 \mathrm{NmlCH}_{4} / \mathrm{gVS}$, corresponding to $27 \%$ of the theoretical yield. Previously, Patinvoh et al. [3] and Forgács et al. [13] found methane yields of 105 (mesophilic condition) and 180 (thermophilic condition), respectively. These yields were low compared to the theoretical methane yield; this is due to the slow degradation of CFs as a result of its recalcitrant structure. An experimental methane yield of $191 \mathrm{NmlCH}_{4} / \mathrm{gVS}$ was obtained from the cattle MS, which is $54 \%$ of the theoretical maximum yield, while $65 \%$ of the theoretical methane yield was obtained from the WS, as shown in Fig. 1. Other studies reported methane yields between 100 and $300 \mathrm{NmlCH}_{4} / \mathrm{gVS}$ for the WS and MS obtained under different conditions [5, 9, $27,28,46]$. 
Fig. 1 Cumulative methane yield during batch anaerobic digestion and theoretical methane potential obtained from COD compositions of individual substrates. Bars represent: grey (bar) experimental yield and red (bar) theoretical yield. (Color figure online)

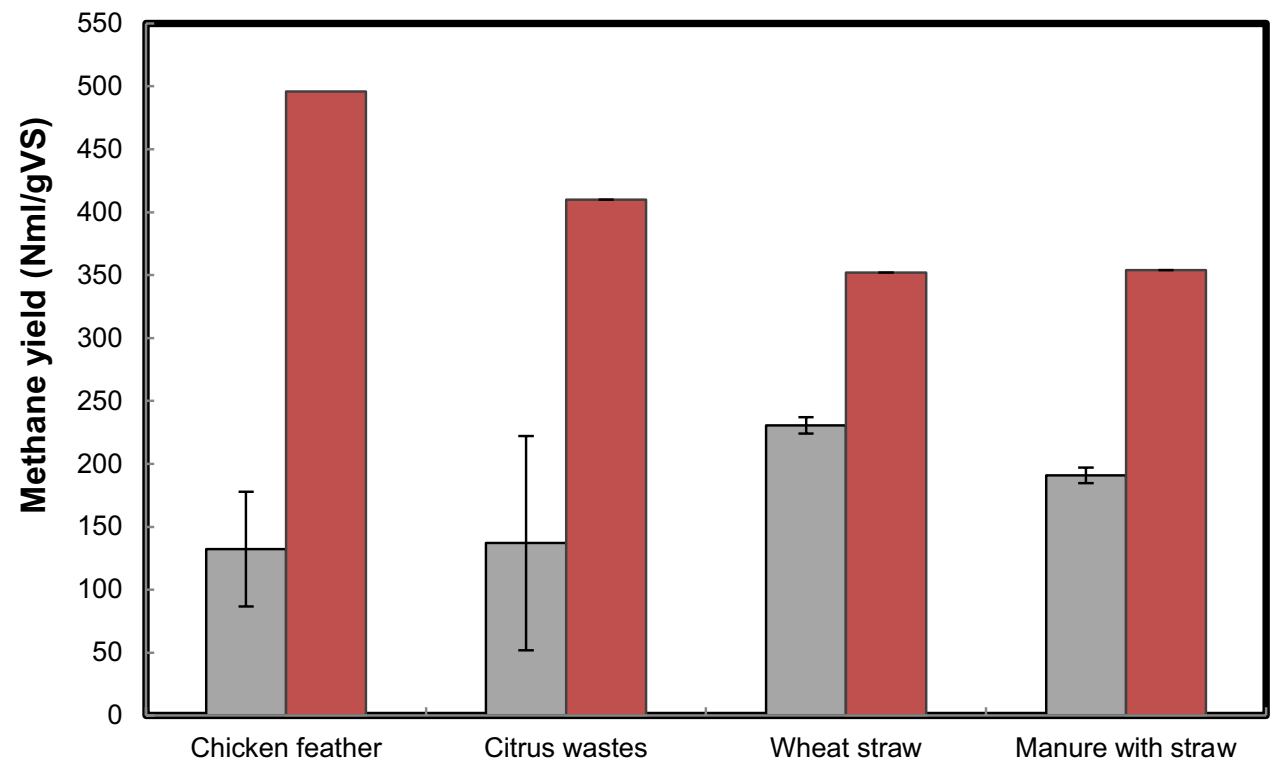

Individual substrates

\section{Methane Yield from Mixtures-Synergetic and Antagonistic Interactions}

Figure 2 shows the cumulative methane production curves obtained for the anaerobic dry co-digestion of CF, CW, WS, and MS during 82 days of digestion period. The compositions of the different mixtures are presented in Table 2. The co-digestion of the various substrate mixtures resulted in methane yields ranging from 165 to $238 \mathrm{NmlCH}_{4} / \mathrm{gVS}$, with the mixing ratio (CF:CW:WS:MS) of 1:1:6:0 (M4), giving the highest methane yield. Figure 3 shows the comparison between the experimental values and the response variables (methane yield) obtained from the linear and quadratic mixing models.

In this work, the expected and predicted methane yields from all the mixtures were modeled using the linear mixing model and the quadratic mixing model respectively. Corresponding methane yields are presented in Fig. 3. Of the mixing models, mixing ratios (CF:CW:WS:MS) of 1:1:5:1 (M2) and 1:1:6:0 (M4) corresponding to $\mathrm{C} / \mathrm{N}$ ratios of 19 and 21 , respectively, gave the best performance, i.e., the methane yield was increased by $12 \%$ and $14 \%$, respectively, compared to values calculated with the linear model. On the other hand, mixing ratios of 1:0:5.8:1.2 (M16) and 1:0:7:0 (M18) having the same $\mathrm{C} / \mathrm{N}$ ratios of 19 and 21 showed antagonistic effects, since the measured methane yields and the calculated methane yields using the quadratic model were $9 \%$ and $11 \%$ lower compared to the values calculated according to the linear model, as shown in Fig. 3.

The experimental results showed synergistic or antagonistic effects, but these were not statistically significant ( $p$-value $>0.05$ ). The results from the mixing ratios showed that the higher the amount of CW and WS in the mixture, the better the methane yield. CF and MS are the ones contributing least to the methane yield; however, the addition of $\mathrm{CF}$ and manure may have contributed to digestion buffering capacity through the release of ammonium cations. Co-digestion of $\mathrm{CW}$ with $\mathrm{CF}$ and WS with a mixing ratio of 1:1:6:0 (M4) gave the highest methane yield; it was therefore chosen for further investigations in continuous process.

\section{Best Mixing Ratio in Continuous Process}

\section{Adaptation Phase}

This phase was carried out in batch mode using the best mixing ratio; this allows for microbial adaptation and conditioning of the feedstock prior to the continuous process. This phase lasted for 28 days, and the daily as well as the cumulative biogas production are presented in Fig. 4. The anaerobic digestion of the best mixing ratio of 1:1:6:0 (M4) in the plug flow reactors were stable. The cumulative methane yield was 270 and $282 \mathrm{NmlCH}_{4} / \mathrm{gVS}$ in reactor $1\left(\mathrm{R}_{1}\right)$ and reactor $2\left(R_{2}\right)$ respectively. During the 28 day of digestion, 571 and 601 of biogas was produced in $R_{1}$ and $R_{2}$, resulting in a TS reduction of $64 \%$ and $73 \%$, respectively. The methane content was $63 \% \pm 2.5$ in $\mathrm{R}_{1}$ and $62 \% \pm 2.9$ in $\mathrm{R}_{2}$. The methane yield obtained during this adaptation phase in the plug flow reactors was between $13 \%$ and $18 \%$ higher than that obtained from this mixing ratio (M4) during the batch digestion test. Minimal mixing in the plug flow reactor provides good contact between the microorganisms and the feedstock, thereby improving the degradation rate and the methane yield. After this adaptation period, and since the 


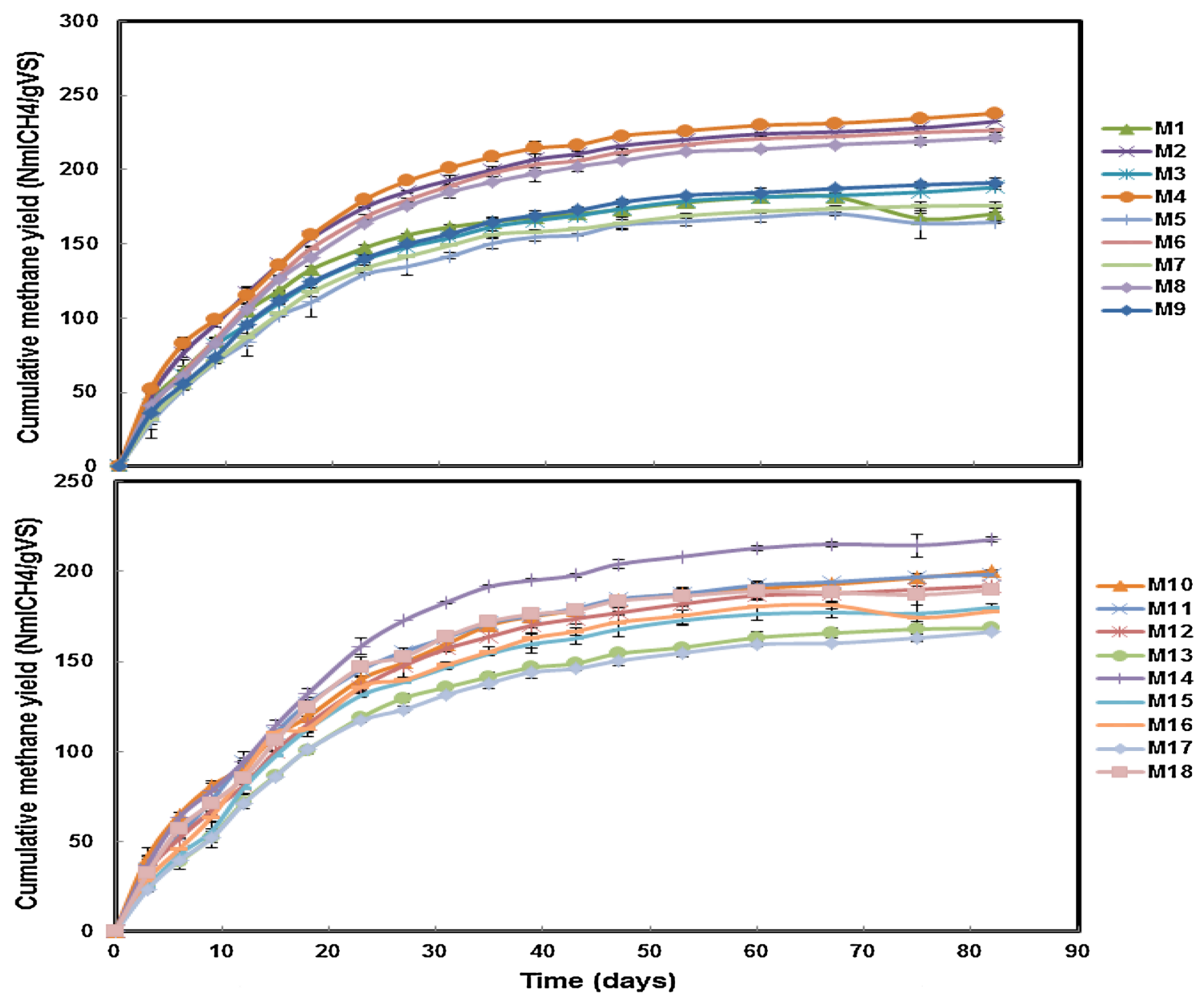

Fig. 2 Cumulative methane yield obtained during the dry co-digestion of the various mixing ratios in batch experiments. The composition of the different mixtures (i.e., M1...M18) can be found in Table 2

co-digestion process was aimed to be studied at dry digestion conditions, the TS in the reactors was increased to $15 \%$ by adding fresh feedstock to the acclimatized inoculum, keeping a VS ratio ( $\mathrm{VS}_{\text {substrate }}$ to $\left.\mathrm{VS}_{\text {inoculum }}\right)$ at 2.5:1.

\section{Process Performance at Different Loading Rates}

The continuous digestion process started after the startup period; continuous operations were carried out at OLR of $2.0 \mathrm{gVS} / \mathrm{L} / \mathrm{d}(\mathrm{OLR} 1)$ and thereafter at $3.8 \mathrm{gVS} / \mathrm{L} / \mathrm{d}$ (OLR 2) in both reactors. The daily biogas production and the methane content in the produced biogas during the continuous operation at different OLR are presented in Fig. 5. During OLR 1 , a biogas production of about $4 \mathrm{~L} / \mathrm{d}$ was obtained from both the reactors at the beginning, which increased slightly and became stable toward the end of the digestion period at OLR1, showing an average of $6.1 \mathrm{~L} / \mathrm{d}$ in $\mathrm{R}_{\mathrm{TS} 21}$ and $5.7 \mathrm{~L} / \mathrm{d}$ in $\mathrm{R}_{\mathrm{TS} 32}$. The methane proportion in the biogas was $60 \%$ in $\mathrm{R}_{\mathrm{TS} 21}$ and $57 \%$ in $\mathrm{R}_{\mathrm{TS} 32}$. The methane yield in $\mathrm{R}_{\mathrm{TS} 21}$ was $362 \mathrm{NmlCH}_{4} / \mathrm{gVS}_{\text {added }}$, which is $13.5 \%$ higher than the yield obtained from $\mathrm{R}_{\mathrm{TS} 32}\left(319 \mathrm{NmlCH}_{4} / \mathrm{gVS}_{\text {added }}\right)$. Chen et al. [47] also reported a decrease in the biogas yield during the continuous dry digestion of swine manure as the TS in the feedstock was increased from $20 \%$ to $35 \%$. However, when the organic loading rate was increased to $3.8 \mathrm{gVS} / \mathrm{L} / \mathrm{d}$ (OLR 2), the daily biogas production increased slightly at the beginning, but this could not be sustained and the biogas production dropped as feeding continued. The methane content also dropped slightly, to an average of $58 \%$ in $\mathrm{R}_{\mathrm{TS} 21}$ and $56 \%$ in $\mathrm{R}_{\mathrm{TS} 32}$.

The $\mathrm{pH}$ was stable, between 7.4 and 7.8 for both reactors, during the digestion period at OLR1 $(2.0 \mathrm{gVS} / \mathrm{L} / \mathrm{d})$, as shown in Fig. 6, in both reactors. Nevertheless, the $\mathrm{pH}$ decreased slightly as the OLR was increased to $3.8 \mathrm{gVS} / \mathrm{L} / \mathrm{d}$ but did not drop below 7.0; hence, it was within the favorable $\mathrm{pH}$ range of $6.8-8$ for the anaerobic digestion processes [48, 49]. At OLR of $2.0 \mathrm{gVS} / \mathrm{L} / \mathrm{d}$ (OLR 1 ), the VFA/alkalinity ratio was below 0.3 for both reactors, which is also within the optimum range required for a stable operation [48]. Furthermore, the total VFA was below $1 \mathrm{~g} / \mathrm{l}$ during this organic loading rate 
Fig. 3 Experimental values and response variables obtained from the various mixtures investigated. Bars represent: grey (bar) methane yield from the quadratic mixing model (predicted yield), red (bar) methane yield from the linear mixing model (expected yield) and green (bar) obtained experimental yield. The composition of the different mixtures (i.e., M1...M18) can be found in Table 2. (Color figure online)

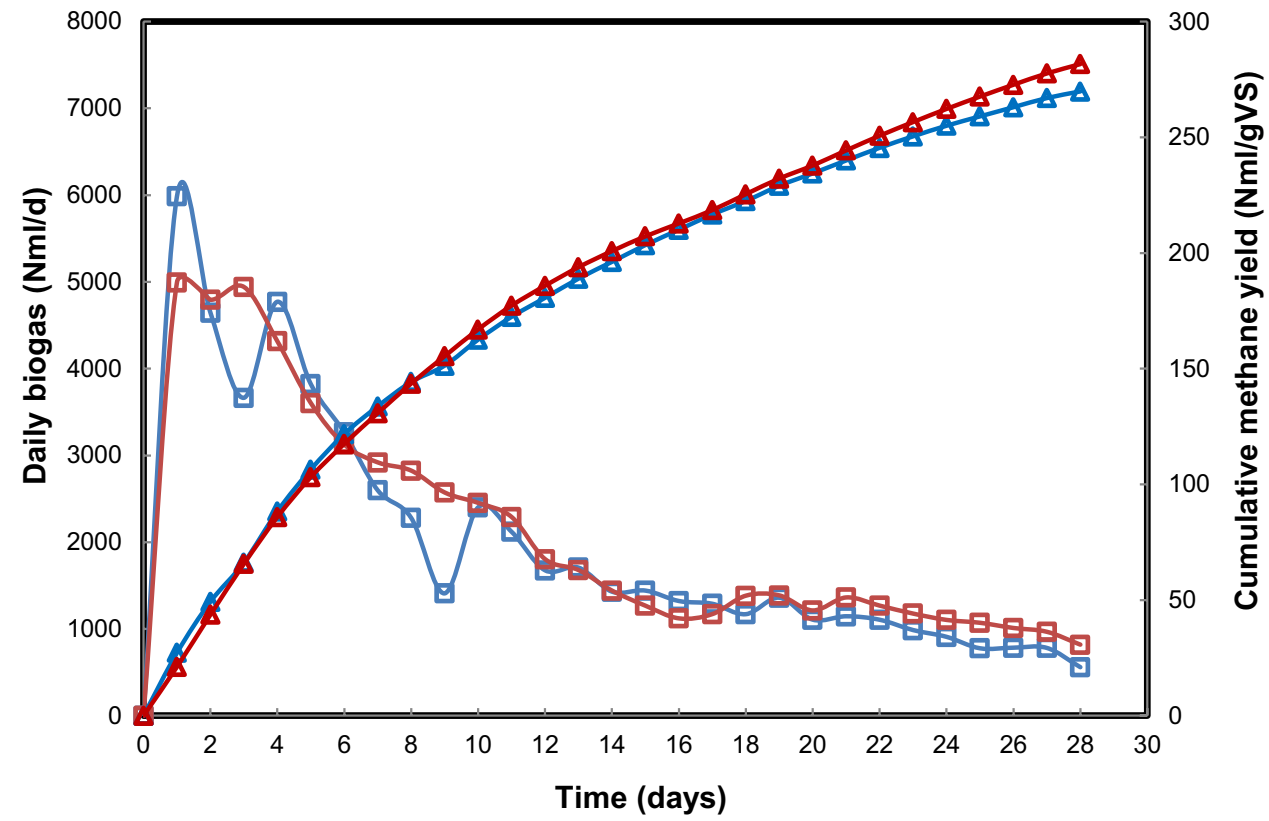

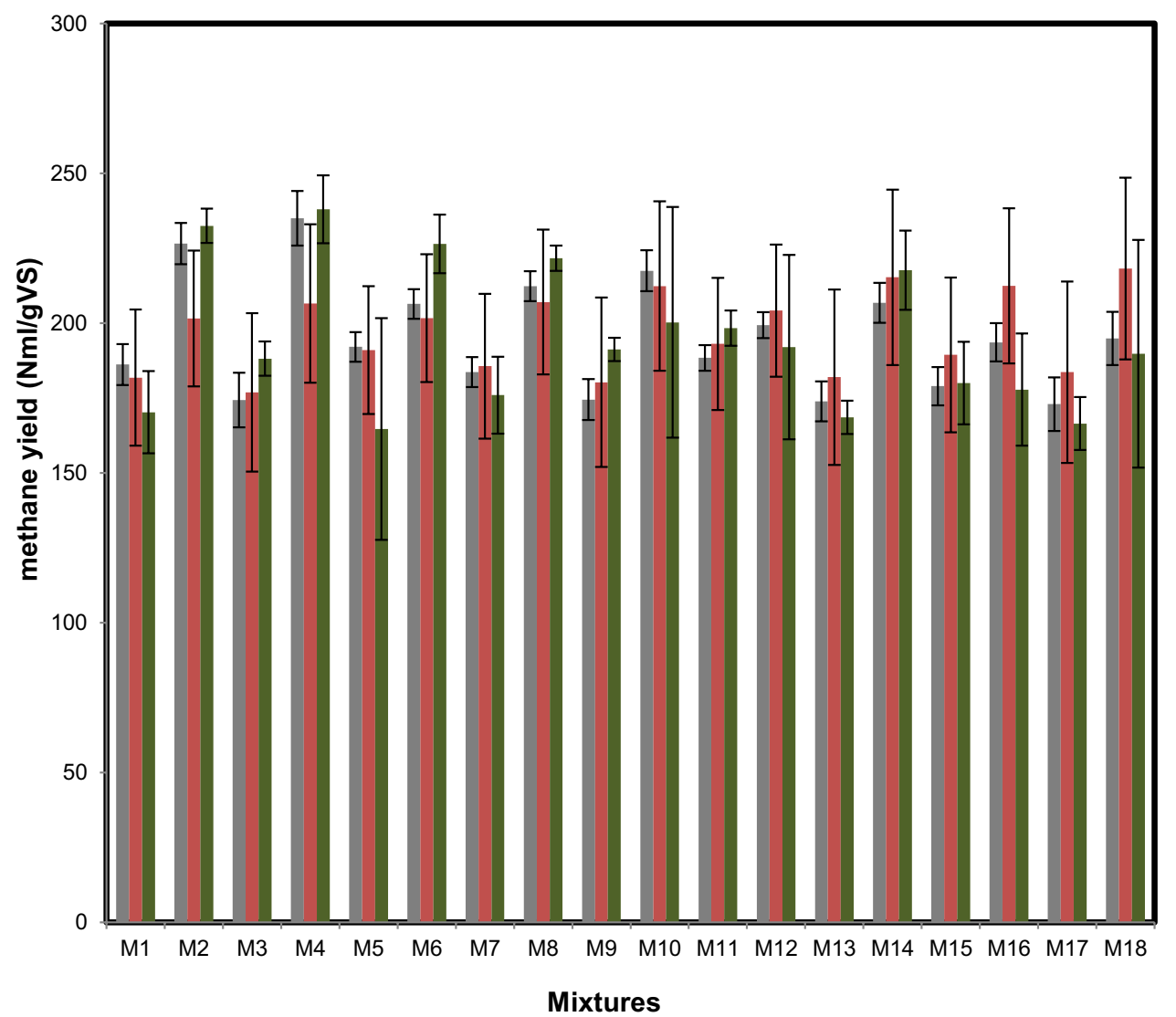

Mixtures
Fig. 4 Daily biogas production and cumulative methane yield obtained during the adaptation phase carried out in batch mode for digestion of the best mixture (M4) in plug flow reactors. Colors represent: blue for reactor 1 (R1) and red for reactor 2 (R2). Symbols represent: square for daily biogas production and triangle for cumulative methane yield. (Color figure online) signifying a stable process [48]. However, the stability of the process declined as the OLR increased to $3.8 \mathrm{gVS} / \mathrm{L} / \mathrm{d}$, with a corresponding retention time of 30 days. The total VFA concentration increased to $8 \mathrm{~g} / \mathrm{l}$ in $\mathrm{R} 1$ and to $4.4 \mathrm{~g} / \mathrm{l}$ in $\mathrm{R} 2$ by the end of the digestion period together with the VFA/alkalinity ratio, which increased sharply, indicating problems in both the reactors (Fig. 6). This resulted in a decline in the biogas production, as shown in Fig. 5. In this study, process 
Fig. 5 Daily biogas production and the methane content of the produced biogas in reactor 1 $\left(\mathrm{R}_{\mathrm{TS} 21}\right)$ and reactor $2\left(\mathrm{R}_{\mathrm{TS} 32}\right)$ during continuous operation; OLR 1 ( $2 \mathrm{gVS} / \mathrm{L} / \mathrm{d}$ for 50 days) and OLR 2 (3.8 gVS/L/d for 30 days). Colors represent: blue for reactor $1\left(\mathrm{R}_{\mathrm{TS} 21}\right)$ and red for reactor $2\left(\mathrm{R}_{\mathrm{TS} 32}\right)$. Symbols represent: square for daily biogas production and triangle for methane content of biogas produced. (Color figure online)

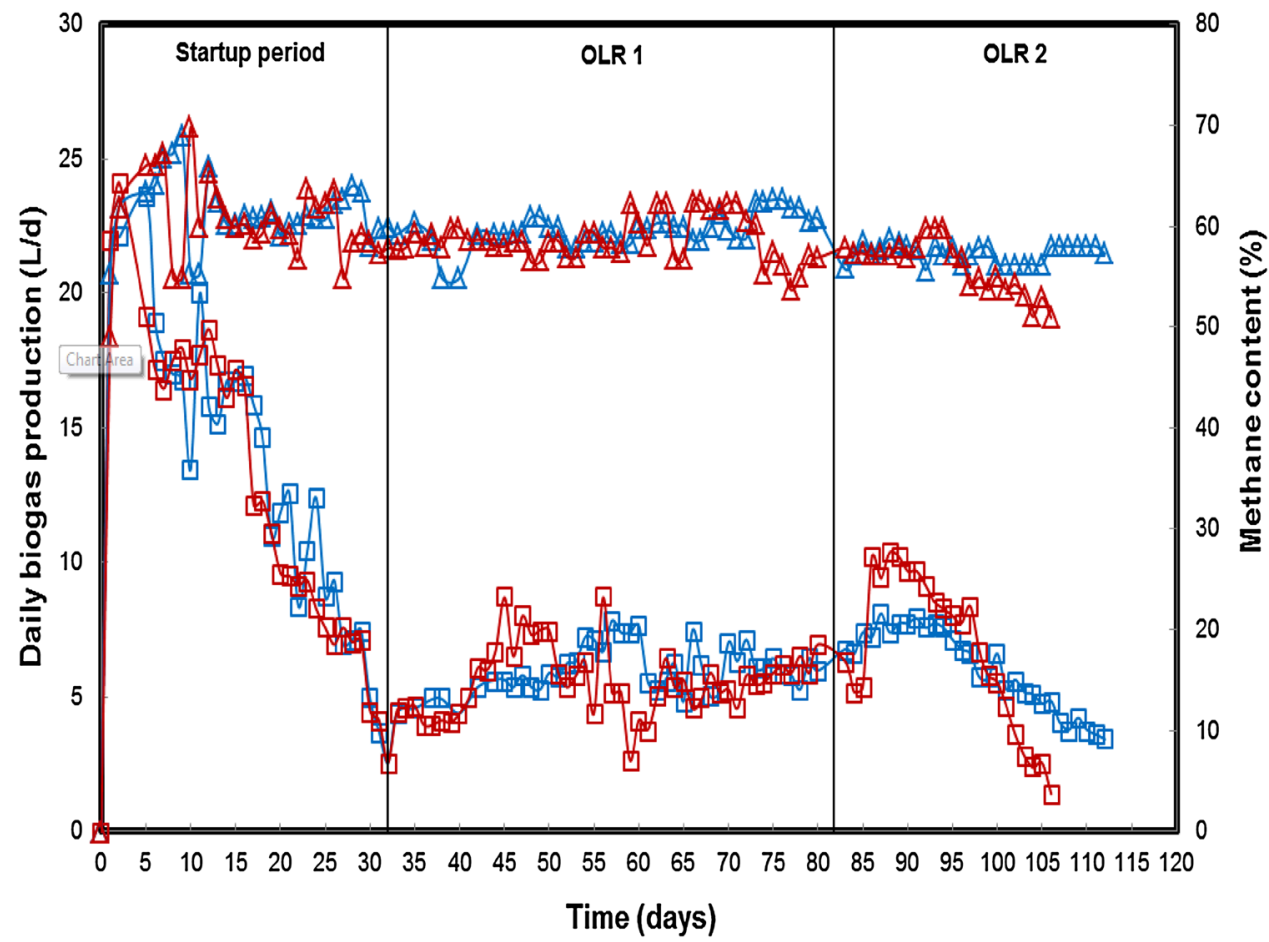

instability was observed at a lower organic loading rate of 3.8 $\mathrm{gVS} / \mathrm{L} / \mathrm{d}$ compared to an OLR of six $\mathrm{gVS} / \mathrm{L} / \mathrm{d}$ reported previously for instability while treating MS at $22 \%$ TS using the continuous plug flow reactor [27]. This can be attributed to the presence of $\mathrm{CW}$ in the co-digestion mixture in this study. For rapidly biodegradable substrates, such as $\mathrm{CW}$, the acidogenic reactions can occur quickly, resulting in VFA accumulation [50]. Co-digestion of fruit, vegetable, and food wastes have been reported to be less stable at an OLR > $2.0 \mathrm{gVS} / \mathrm{L} / \mathrm{d}$ [51] because of the accumulation of propionate. In addition, the total ammonia concentration was slightly higher in $\mathrm{R}_{\mathrm{TS} 32}$ than in $\mathrm{R}_{\mathrm{TS} 21}$, as shown in Fig. 6; this could be the result of the moisture content reduction in $\mathrm{R}_{\mathrm{TS} 32}$. Chen et al. [47] also reported high ammonia nitrogen concentration when the TS concentration of feedstock was increased from $20 \%$ to $35 \%$ in continuous dry fermentation of swine manure.

At OLR1 $(2.0 \mathrm{gVS} / \mathrm{L} / \mathrm{d})$, the TS content of digestate was $9.8 \% \pm 0.34$ in $\mathrm{R}_{\mathrm{TS} 21}$ and $11.12 \pm 0.69$ in $\mathrm{R}_{\mathrm{TS} 32}$. As the OLR increased to $3.8 \mathrm{gVS} / \mathrm{L} / \mathrm{d}$, the TS content of the digestate increased to $10.02 \pm 0.55 \%$ in $\mathrm{R}_{\mathrm{TS} 21}$ and to $12.1 \pm 0.45 \%$ in $\mathrm{R}_{\mathrm{TS} 32}$. Additionally, reactor $2\left(\mathrm{R}_{\mathrm{TS} 32}\right)$, which was fed with a feedstock of $32 \%$ TS, was blocked toward the end of feeding with OLR of $3.8 \mathrm{gVS} / \mathrm{L} / \mathrm{d}$; there were problems both with the feeding and with the discharge of the digestate residue.

\section{Conclusions}

Co-digestion of $\mathrm{CW}, \mathrm{CF}$ and WS with a mixing ratio of 1:1:6 gave the best performance in batch dry digestion process, with a methane yield of $238 \mathrm{Nml} / \mathrm{gVS}$. The methane yields obtained during the adaptation phase in the plug flow reactors were between $13 \%$ and $18 \%$ higher than the obtained yield from the best mixture (M4 i.e., 1:1:6) during the batch anaerobic digestion process. Continuous dry digestion of the best mixture at $21 \%$ TS and $32 \%$ TS in the feed was successful with OLR of $2 \mathrm{gVS} / \mathrm{L} / \mathrm{d}$ and corresponding retention time of 50 days. OLR of $3.8 \mathrm{gVS} / \mathrm{L} / \mathrm{d}$ with corresponding retention time of 30 days favoured process instability at both total solid content of feed considered (21\% TS and 32\% TS). This instability in the process performance resulted into volatile fatty acids accumulation and subsequent reduction in biogas production. 


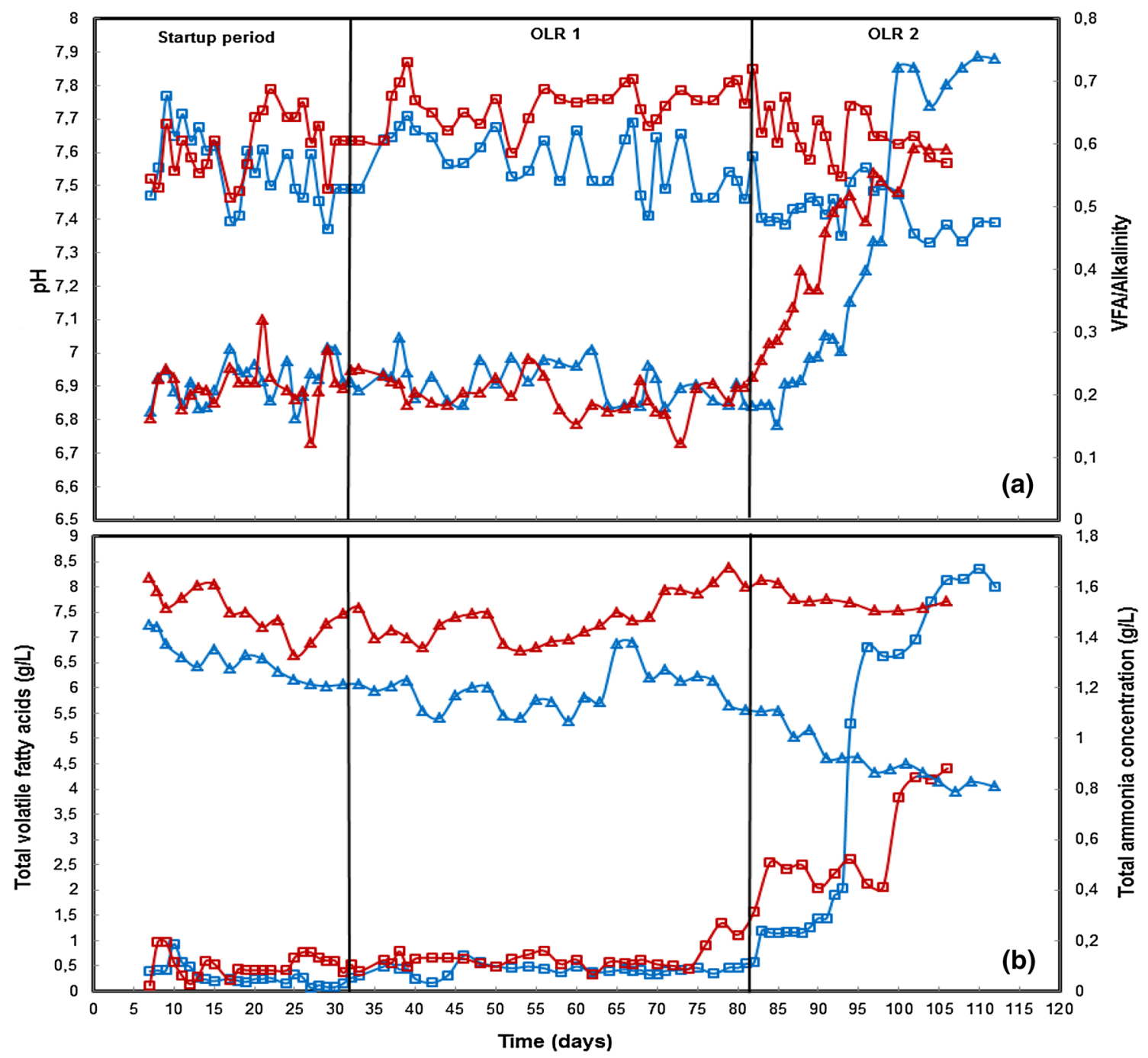

Fig. 6 Variation in pH, VFA/alkalinity ratio, total VFA, and total ammonia concentration in reactor $1\left(\mathrm{R}_{\mathrm{TS} 21}\right)$ and reactor $2\left(\mathrm{R}_{\mathrm{TS} 32}\right)$ during continuous operation; OLR 1 ( $2 \mathrm{gVS} / \mathrm{L} / \mathrm{d}$ for 50 days) and OLR 2 (3.8 gVS/L/d for 30 days). Colors represent: blue for reactor $1\left(\mathrm{R}_{\mathrm{TS} 21}\right)$

Acknowledgements This work was financially supported by the Research and Educational Board of the University of Borås and Region Västra Götaland (Sweden).

Open Access This article is distributed under the terms of the Creative Commons Attribution 4.0 International License (http://creativeco mmons.org/licenses/by/4.0/), which permits unrestricted use, distribution, and reproduction in any medium, provided you give appropriate credit to the original author(s) and the source, provide a link to the Creative Commons license, and indicate if changes were made.

\section{References}

1. Jensen, J.E.F., Pipatti, R.: CH4 emissions from solid waste disposal. Background paper on Good Practice Guidance and Uncertainty Management in National Greenhouse Gas and red for reactor $2\left(\mathrm{R}_{\mathrm{TS} 32}\right)$. Symbols represent: a Square and triangle for $\mathrm{pH}$ and VFA/alkalinity ratio respectively $\mathbf{b}$ square and triangle for total VFAs concentration and total ammonia concentration respectively. (Color figure online)

Inventories 2002, 2017/09/07; Available from: http://www. ipcc-nggip.iges.or.jp/public/gp/bgp/5_1_CH4_Solid_Waste.pdf (2002)

2. Curry, N., Pillay, P.: Biogas prediction and design of a food waste to energy system for the urban environment. Renewable Energy 41, 200-209 (2012)

3. Patinvoh, R.J., et al.: Biological pretreatment of chicken feather and biogas production from total broth. Appl. Biochem. Biotechnol. 180(7), 1401-1415 (2016)

4. Salminen, E., Einola, J., Rintala, J.: The methane production of poultry slaughtering residues and effects of pretreatments on the methane production of poultry feather. Environ. Technol 24(9), 1079-1086 (2003)

5. Schnürer, A., Jarvis A.: Microbiological handbook for biogas plants. Swedish Waste Management U2009:03. Available from: http://www.eacquality.net/fileadmin/eac_quality/user_docum ents/3_pdf/Microbiological_handbook_for_biogas_plants.pdf. Accessed 9 Feb 2017 (2010) 
6. Sharma, K., et al.: Converting citrus wastes into value-added products: economic and environmently friendly approaches. Nutrition 34(Suppl C), 29-46 (2017)

7. Chandra, R., et al.: Improving biodegradability and biogas production of wheat straw substrates using sodium hydroxide and hydrothermal pretreatments. Energy 43(1), 273-282 (2012)

8. Bolado-Rodríguez, S., et al.: Effect of thermal, acid, alkaline and alkaline-peroxide pretreatments on the biochemical methane potential and kinetics of the anaerobic digestion of wheat straw and sugarcane bagasse. Bioresour. Technol. 201, 182-190 (2016)

9. Aslanzadeh, S., Taherzadeh, M.J., Horváth, I.S.: Pretreatment of straw fraction of manure for improved biogas production. BioResources 6(4), 5193-5205 (2011)

10. Lohrasbi, M., et al.: Process design and economic analysis of a citrus waste biorefinery with biofuels and limonene as products. Bioresour. Technol. 101(19), 7382-7388 (2010)

11. Forgács, G., et al.: Methane production from feather waste pretreated with $\mathrm{Ca}(\mathrm{OH})_{2}$ : process development and economical analysis. Waste Biomass Valoriz. 5(1), 65-73 (2014)

12. Theuretzbacher, F., et al.: Steam explosion pretreatment of wheat straw to improve methane yields: investigation of the degradation kinetics of structural compounds during anaerobic digestion. Bioresour. Technol. 179, 299-305 (2015)

13. Forgács, G., et al.: Biological treatment of chicken feather waste for improved biogas production. J. Environ. Sci. 23(10), 1747$1753(2011)$

14. Plöchl, M., et al.: Application of hydrolytic enzymes for improving biogas feedstock fluidity. Agric. Eng. Int.:CIGR e-journal 11, $1-16(2011)$

15. Mizuki, E., Akao, T., Saruwatari, T.: Inhibitory effect of citrus unshu peel on anaerobic digestion. Biol. Wastes 33(3), 161-168 (1990)

16. Wikandari, R., et al.: Improvement of biogas production from orange peel waste by leaching of limonene. BioMed Res. Int. 2015, 1-6 (2015)

17. Forgács, G., et al.: Methane production from citrus wastes: process development and cost estimation. J. Chem. Technol. Biotechnol. 87(2), 250-255 (2012)

18. Wikandari, R., et al.: Biogas production from citrus waste by membrane bioreactor. Membranes 4(3), 596-607 (2014)

19. Patinvoh, R.J., et al.: Innovative pretreatment strategies for biogas production. Bioresour. Technol. 224, 13-24 (2017)

20. Mata-Alvarez, J., et al.: A critical review on anaerobic co-digestion achievements between 2010 and 2013. Renew. Sustain. Energy Rev. 36, 412-427 (2014)

21. Bachmann, N.: Sustainable biogas production in municipal wastewater treatment plants. eBook electronic edition. Available from: http://www.iea-biogas.net/files/datenredaktion/download/Techn ical\%20Brochures/Wastewater_biogas_grey_web-1.pdf. 25 June 2016 (2015)

22. Friehe, J., Weiland, P., Schattauer, A.: Fundamentals of anaerobic digestion. in: Guide to Biogas FromProduction to Use. Fachagentur Nachwachsende Rohstoffe e. V. (FNR). 5th revisededition. Available from:https://mediathek.fnr.de/media/downloadable/ files/samples/g/u/guide_biogas_engl_2012.pdf. Accessed 31 May $2016(2010)$

23. Liu, X., et al.: Effects of organic matter and initial carbon-nitrogen ratio on the bioconversion of volatile fatty acids from sewage sludge. J. Chem. Technol. Biotechnol. 83(7), 1049-1055 (2008)

24. Pagés Díaz, J., et al.: Co-digestion of different waste mixtures from agro-industrial activities: kinetic evaluation and synergetic effects. Bioresour. Technol. 102(23), 10834-10840 (2011)

25. Herrmann, C., et al.: Optimised biogas production from microalgae through co-digestion with carbon-rich co-substrates. Bioresour. Technol. 214, 328-337 (2016)
26. Kabir, M.M., Taherzadeh, M.J., Sárvári Horváth, I.: Dry anaerobic digestion of lignocellulosic and protein residues. Biofuel Res. J. 2(4), 309-316 (2015)

27. Patinvoh, R.J., et al.: Dry fermentation of manure with straw in continuous plug flow reactor: reactor development and process stability at different loading rates. Bioresour. Technol. 224, 197 205 (2017)

28. Patinvoh, R.J., et al.: Cost effective dry anaerobic digestion in textile bioreactors: experimental and economic evaluation. Bioresour. Technol. 245(Part A), 549-559 (2017)

29. Zeshan, O.P., Karthikeyan, Visvanathan, C.: Effect of $\mathrm{C} / \mathrm{N}$ ratio and ammonia-N accumulation in a pilot-scale thermophilic dry anaerobic digester. Bioresour. Technol. 113, 294-302 (2012)

30. Liew, L.N., Shi, J., Li, Y.: Methane production from solid-state anaerobic digestion of lignocellulosic biomass. Biomass Bioenerg. 46, 125-132 (2012)

31. Li, Y., Park, S.Y., Zhu, J.: Solid-state anaerobic digestion for methane production from organic waste. Renew. Sustain. Energy Rev. 15(1), 821-826 (2011)

32. Yang, L., et al.: Challenges and strategies for solid-state anaerobic digestion of lignocellulosic biomass. Renew. Sustain. Energy Rev. 44, 824-834 (2015)

33. Zupančič, G.D., Roš, M.: Determination of chemical oxygen demand in substrates from anaerobic treatment of solid organic waste. Waste Biomass Valoriz. 3, 89-98 (2012)

34. Nielfa, A., Cano, R., Fdz-Polanco, M.: Theoretical methane production generated by the co-digestion of organic fraction municipal solid waste and biological sludge. Biotechnol. Rep. 5, 14-21 (2015)

35. Tarvin, D., Buswell, A.M.: The methane fermentation of organic acids and carbohydrates 1, 2. J. Am. Chem. Soc. 56(8), 1751-1755 (1934)

36. Angelidaki, I., Sanders, W.T.M.: Assessment of the anaerobic biodegradability of macropollutants. Rev. Environ. Sci. Biotechnol. 3(2), 117-129 (2004)

37. Angelidaki, I., et al.: Defining the biomethane potential (BMP) of solid organic wastes and energy crops: a proposed protocol for batch assays. Water Sci. Technol. 59(5), 927-934 (2009)

38. APHA-AWWA-WEF: Standard Methods for the Examination of Water and Wastewater, 21st edn. American Public Health Association (APHA), American Water Works Association (AWWA), Water Environment Federation (WEF), Washington DC (2005)

39. Zhou, C., et al.: A new strategy for co-composting dairy manure with rice straw: addition of different inocula at three stages of composting. Waste Manage. 40, 38-43 (2015)

40. Zhang, Y., Ghaly, A.E., Li, B.: Physical properties of wheat straw varieties cultivated under different climatic and soil conditions in three continents. Am. J. Eng. Appl. Sci. 5(2), 98-106 (2012)

41. Sluiter, A., et al.: Determination of extractives in biomass. Laboratory Analytical Procedure (LAP). NREL/TP-510-42619. Available from: http://www.nrel.gov/biomass/pdfs/42619.pdf (2008)

42. Sluiter, A., et al.: Determination of structural carbohydrates and lignin in biomass. Laboratory Analytical Procedure. NREL/ TP-510-42618. Available from: http://www.nrel.gov/biomass/ pdfs/42618.pdf (2011)

43. Lossie, U., Pütz, P.: Targeted control of biogas plants with the help of FOS/TAC. Practice Report, Laboratory Analysis Titration FOS/ TAC. HACH LANGE. Laboratory Analysis Titration FOS/TAC [Practice Report]. Available from: https://tr.hach.com/asset-get. download.jsa?id=25593611361 (2008)

44. Teghammar, A., et al.: Pretreatment of paper tube residuals for improved biogas production. Bioresour. Technol. 101(4), 12061212 (2010)

45. Pourbafrani, M., et al.: Production of biofuels, limonene and pectin from citrus wastes. Bioresour. Technol. 101(11), 4246-4250 (2010) 
46. Kusch, S., Oechsner, H., Jungbluth, T.: Biogas production with horse dung in solid-phase digestion systems. Bioresour. Technol. 99(5), 1280-1292 (2008)

47. Chen, C., et al.: Continuous dry fermentation of swine manure for biogas production. Waste Manage. 38, 436-442 (2015)

48. Drosg, B.: Process Monitoring in Biogas Plants, pp. 1-38. IEA Bioenergy, Paris. 978-1-910154-03-8. Available from: http:// www.iea-biogas.net/files/datenredaktion/download/Technical\%20 Brochures/Technical\%20Brochure\%20process_montoring.pdf (2013)
49. Lahav, O., Morgan, B.E.: Titration methodologies for monitoring of anaerobic digestion in developing countries - a review. J. Chem. Technol. Biotechnol. 79(12), 1331-1341 (2004)

50. Comino, E., Rosso, M., Riggio, V.: Investigation of increasing organic loading rate in the co-digestion of energy crops and cow manure mix. Bioresour. Technol. 101(9), 3013-3019 (2010)

51. Shen, F., et al.: Performances of anaerobic co-digestion of fruit $\&$ vegetable waste (FVW) and food waste (FW): single-phase vs. two-phase. Bioresour. Technol. 144(Suppl C), 80-85 (2013) 